\title{
The Effect of Mangala, the Intelligence Game Taught by Distance Education, on the Mathematical Motivations and Problem-solving Skill Levels of $6^{\text {th }}$-Grade Students
}

\author{
Neslihan Usta ${ }^{1}$ \& Büşra Cagan ${ }^{2}$ \\ ${ }^{1}$ Bartin University, Education Faculty, Mathematics Education, Bartin, Turkey \\ ${ }^{2}$ Bartin University, Graduate School and MoNE, Bartin, Turkey \\ Correspondence: Neslihan Usta, Department of Faculty of Education, Mathematics and Science Science \\ Education, Mathematics Education, Bartin University, Bartin, Turkey. E-mail: neslihanusta74@gmail.com \\ ORCID ID: 0000-0003-2662-1975
}

Received: November 2, 2021

Accepted: December 2, 2021

Online Published: December 4, 2021

doi:10.5539/hes.v12n1p9

URL: https://doi.org/10.5539/hes.v12n1p9

\begin{abstract}
This study examines the effect of "Mangala" on the mathematical motivation and problem-solving skill levels (PSoSL) of $6^{\text {th }}$-grade students. A single-group pre-test-post-test quasi-experimental design based on the quantitative research approach was used in the study conducted through distance education. The sample consisted of $146^{\text {th }}$-grade students. The data collection tools used in the study, which continued for three weeks in the 2020-2021 academic year, were the Mathematical Motivation Scale (MMS) and Performance Tasks (PT). The data obtained from this study were analyzed using the SPSS 22.0 package program. Since the sample size was small and the data did not show normal distribution, data analysis was carried out using the Wilcoxon Signed Rank Test, one of the non-parametric statistical tests. Data analysis showed a statistically significant difference between the pre and post-experiment MMS scores of the students. The effect of "Mangala" on students' PSoSL was evaluated through performance tasks. The Progressive Scoring Scale (PSS) taken from Baki (2014) was used to evaluate performance tasks. Researchers redefined each criterion in the scoring key and set four levels: "very good," "good," "unsatisfactory," and "empty." The analysis of the problems in the performance tasks showed that the students usually gave "very good" and "good" answers. However, some students had difficulties finding solution strategies and writing a similar problem; thus, they left blank answers.
\end{abstract}

Keywords: Mangala, distance education, mathematical motivation, problem-solving skill level, performance task

\section{Introduction}

Distance education is a model in which teachers and students do not have to be in the same places (National Center for Education Statistics [NCES], 2008), and education activities are carried out through information and communication technologies (İşman, 2011). In the distance education process, students and teachers are physically in separate environments, and they connect with teaching resources and each other through various interactive communication technologies (Simonson, Smaldino, Albright, \& Zvacek, 2012).

In distance education models, vast audiences can receive the necessary training from wherever they want, whenever they want. This situation offers various possibilities for individuals who do not have the opportunity to receive education, especially for the courses that cannot be done face-to-face in formal education during the current Covid-19 pandemic to be performed online. Some of them are repeating the courses asynchronously over the internet and at the desired time and conducting exams by distance education. In addition, the opportunity to repeat the teaching subjects more than once and the higher number of exams make distance education efficient (Dinçer, 2006).

In distance education, two-way communication between the teacher and students and meeting students' needs is essential. Besides, in distance education, students should take responsibility for their learning, be determined, and be more active in the process (Moore, 1989). According to Holmberg (1997), active participation in the lesson and learning environments gives the student a sense of belonging, establishes a comfortable communication with the teacher, and makes learning more enjoyable. Therefore, learning pleasure and 
participation in decision-making processes have positive reflections on student motivation. One of the active learning methods in which the student is active and willingly participates in the learning environment is learning with games. Games are indispensable activities present in every period of life and used in different situations and purposes (Uğurel \& Moralı, 2008). Studies show that game increases individual's motivation (Rosas, Nussbaum, Cumsille, Marianov, Correa, Flores, Grau, Lagos, López, López, Rodriguez, \& Salinas, 2003) and concentration (Garris, Ahlers, \& Driskell, 2002) and contributes to developing a positive attitude towards learning. (Lou, Abrami, \& D'Apollonia, 2001). One of the types of intelligence games that can be used in teaching mathematics is strategy games. Strategic intelligence games are defined as "games in which two or more players play competitively against each other, the decisions they make in the game affect the course and outcome of the game, the opponent's moves should be taken into account in the decisions taken, and there is a winner and a loser at the end of the game" (Erdoğan, Eryılmaz Çevirgen \& Atasay, 2017).

Many intelligence games are based on the adaptation of mathematical objects, facts, problems, and concepts (Pintér, 2010; Silva, 2011), which strengthens the belief that there is a close relationship between intelligence games and mathematics (Erdoğan, Eryılmaz Çevirgen, \& Atasay, 2017). Understanding mathematical knowledge and establishing a relationship between these pieces of knowledge occurs in the problem-solving process (Swings \& Peterson, 1988); thus, problem-solving is at the center of mathematics teaching programs (Karataş \& Güven, 2003). Therefore, problem-solving is an essential component of doing math. It is necessary to face students with various problem situations and help them develop solution strategies to improve their problem-solving skill levels (PSoSL). Kurbal (2015) reported that intelligence games improved $6^{\text {th }}$-grade students' problem-solving strategies, and the students found the games entertaining and valuable. Karasar (2003) expresses every situation that disturbs the individual physically or mentally, gives indecision, and has more than one possible solution as a problem. Different researchers have defined various problem-solving steps. However, the most used problem-solving process in mathematics is Polya's (1957) four-step problem-solving process. Understanding the problem is the first step in this process. The second step is devising a plan suitable for the problem. The third is carrying out the plan or solution strategy. The fourth step is looking back-checking and interpreting. Writing a similar problem is considered a separate stage of the looking back step. Polya (1957) suggested many strategies for solving routine and non-routine problems. For example, pattern search, strategies aiming to focus on the relationship between what is given in the problem and what is asked, and creating tables aiming at systematic thinking and reasoning. According to Polya, strategy knowledge and its use are essential in solving problems. However, what is more important is providing students with the proficiency/competence of strategic thinking. Strategic intelligence games require coming out of a problem situation as a winner, accomplishing a task before the opponent, and establishing some cognitive schemes to perform all these operations systematically (Erdoğan, Eryılmaz Çevirgen, \& Atasay, 2017). From this, it is understood that there is a strong relationship between problem-solving and strategic games. One of the intelligence games that require strategic thinking is "Mangala," a traditional Turkish intelligence and strategy game that includes strategic thinking, analysis, and foresight and can be played by players of all ages (see Figure 1). Mangala provides players with social skills, fine motor development, and concentration for children (Uluışık, 2018; Özkaya, 2021). Zaslavsky (1979) states that "Mangala" contributes to the development of mathematical thinking, high-level strategic thinking, and problem-solving skills (Zaslavsky, 1979, cited in Ismael, 2001).

\subsection{How to Play Mangala?}

Mangala is a traditional strategy game played in different ways (Musesti, Paolini, \& Reale, 2015). It is usually played with two people on a game board containing 12 small pits, 2 large pits (treasure), and 24 stones at the zone of each player. At the beginning of the game, four stones are placed in each small pit. The player who starts the game takes four stones from one of the small pits in his/her area and drops one stone back into the pit from which he/she took it. Then he/she continues to the right (counterclockwise) by dropping one stone into each pit until he/she runs out of stone. The player leaves a stone while passing across his/her treasure but does not drop when passing across the opponent's treasure. If the last stone in the player's hand falls into his/her treasury, he/she has the right to play another turn. If the player who distributes the stones has stones remaining in his/her hand, he/she will pass to the opponent's territory and continue to drop stones in the opponent's pits. In this case, if the player's last stone makes the number of stones in the opponent's pit an even number, he/she takes all stones in this pit and puts them in his/her treasury. Suppose the last stone is put in an empty pit in his/her area, and the opponent has stones in the pit opposite it; then he/she takes both the stone left in the empty pit and the stones in the opponent's pit and put them in his/her treasury. In this case, the turn passes to the opponent. The player who first finishes the stones in his/her area wins all the stones in the opponent's pits. When the player runs out of stone, the turn passes to the opponent. The objective of this game is to collect the most stones in the treasures. 
The player with the most stones in his/her treasury wins the first set of the game. The game is usually played over five sets (Küçükyıldız, 2020; Özkaya, 2021).

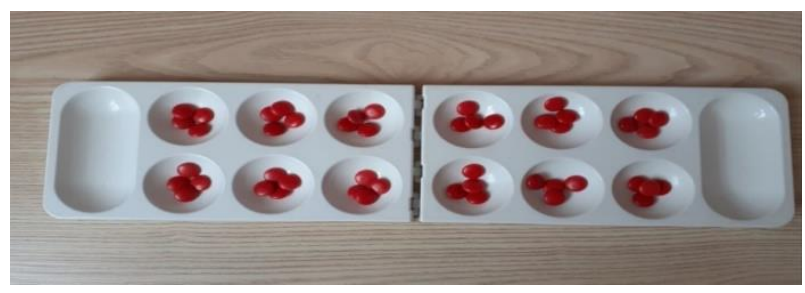

Figure 1. Mangala Game

In learning and teaching mathematics, affective factors such as interest, attitude, and motivation are as important as cognitive factors (Sönmez, 2010; Uluçay \& Güven, 2017). Student motivation is an essential component in improving the quality of education. Motivation is a concept related to how individuals are treated and how they feel about their work (Keenan, 1996, cited in Özdemir \& Öner, 2015). According to Adler, Milne, and Stablein (2001), motivation is the degree of continuity of an individual's attempts to take action and achieve his goal. Motivation is a driving force for students to be successful, to work hard at school, and to learn (Martin, 2001, cited in Yaman \& Dede, 2007), which shows that it has a significant effect on learning (Glynn, Aultman \& Owens 2005; Lumsden, 1994). Being active in the learning process increases students' motivation, and participation in decisions positively affects their value systems, mental structures, and motivations (Batlaş, 2002, cited in Akbaba, 2006).

Considering the positive and significant relationship between motivation and achievement (Akbaba, 2006; Herges, Duffield, Martin, \& Wageman, 2017; Moenikia \& Zahed Babelon, 2010), ensuring student motivation towards mathematics courses is crucial in the process of learning mathematics. Mathematical motivation is defined as students' willingness to learn mathematics and their active participation in mathematical tasks (İspir, Ay, \& Sayg1, 2011). Motivated students are attentive; they start working on their tasks, ask questions, give voluntary answers, and seem happy and eager (Palmer, 2007).

Ensuring student motivation in the classroom is an essential component in learning (Ersoy \& Başer, 2010). If the teacher designs practical learning tools for students and uses classroom activities with appropriate strategies and methods, students' interest in learning will increase (Rifandi, 2013).

\subsection{The Significance of the Study and its Contribution to the Literature}

In the $21^{\text {st }}$ century, where science and technology are developing rapidly, teaching offers various alternatives. One of them is distance education. Especially in the last two years, the Covid-19 pandemic, which has affected the world, has imprisoned people in their homes and made the distance education alternative mandatory.

As the affective factors are as important as cognitive factors in learning, the motivation of students who cannot attend school and who are deprived of the classroom atmosphere should be increased. Motivation, which can be defined as the willingness to work and participation in the tasks, is one of the affective factors. According to Palmer (2007), motivated individuals are attentive, and they try to fulfill their duties in the best way, ask questions, participate in studies willingly, and appear happy and eager. To motivate their students towards learning is crucial for the teachers, who are one of the essential components of the teaching-learning environment, to increase the quality of teaching. The task of teachers is not only to know what motivates their students but also to help them enhance and improve their motivation and prepare motivational situations.

One of the main objectives of the Mathematics Curriculum is to develop students' PSoSL. For this reason, problem-solving is at the center of the curriculum. In the light of studies on distance education in the literature, it was thought that there might be a positive and significant relationship between students' mathematical motivation and PSoSL, which is one of the basic skills of the $21^{\text {st }}$ century. In addition, there is no study in the literature on the reflection of teaching and playing "Mangala," a strategic intelligence game, through distance education on $6^{\text {th }}$-grade students' mathematical motivation and PSoSL. Thus it was decided to conduct this study. Besides, this study was carried out with the idea that games can be used to increase motivation towards mathematics lessons in the distance education process. The study aimed to teach and play the strategic game "Mangala" and determine its effect on students' mathematical motivation and PSoSL. In addition, the significance of the relationship between mathematical motivation and PSoSL was investigated. Therefore, the 
original value of the study lies in its purpose. In this context, it is thought that this study will contribute to the literature.

\subsection{The Purpose of the Study and Research Problems}

This study aims to examine the effect of "Mangala," taught by distance education, on $6^{\text {th }}$-grade students' mathematical motivation and PSoSL and investigate whether there is a statistically significant relationship between mathematical motivation and PSoSL. In this direction, the sub-problems addressed in the study are as follows:

1) Does "Mangala," taught by distance education, create a statistically significant difference between $6^{\text {th }}$-grade students' pre and post-test mathematical motivation scores?

2) What are the PSoSL of $6^{\text {th }}$-grade students learning and playing "Mangala" through distance education?

3) Is there a statistically significant relationship between PSoSL and the mathematical motivations of $6^{\text {th }}$-grade students?

\section{Methodology}

\subsection{Research Design}

Qualitative and quantitative approaches were used together in the study. The research design was set as a single-group pre-test post-test weak quasi-experimental design. In a single-group pre-test post-test design, the independent variable is implemented, and measurement is made before and after the implementation (Karasar, 2003). In the study, the quantitative approach was used to analyze the data that measured students' mathematical motivation using non-parametric tests and determine whether there is a statistically significant difference between mathematical motivation and PSoSL. Besides, the qualitative approach was employed by using descriptive analysis to determine PSoSL.

\subsection{Study Group}

This study was conducted with 14 students attending $6^{\text {th }}$-grade of a public school in the Marmara Region of Turkey in the 2020-2021 academic year. The socio-economic levels of the students participating in the study were moderate, and all of them have participated voluntarily. Instead of the students' real names, codes such as $\mathrm{S} 1, \mathrm{~S} 2, \ldots, \mathrm{S} 14$ were used.

\subsection{Data Collection}

In the study, MMS was used to measure students' mathematical motivation and PTs to determine PSoSL.

\subsubsection{MMS}

MMS, developed by Üzel, Uyangör, Damage, and Çakır (2018), was administered to measure the mathematical motivation of the students participating in the study before and after the implementation. The Cronbach alpha reliability coefficient of the scale was .88 . The scale consisted of 26 five-point Likert type items scored as "I totally agree, agree, undecided, disagree and totally disagree." 18 of the items were positive, and 8 were negative.

\subsubsection{PT}

Two performance tasks (see Appendix A), related to the gains given in the $6^{\text {th }}$-grade Mathematics Curriculum (MoNE, 2018), have been prepared to examine the effect of "Mangala" on students' PSoSL.

1) Writing the algebraic expression of a verbally given problem and the verbal expression of a given algebraic problem.

2) Calculating the value of algebraic expressions for the natural numbers that the variable will take. Explaining the meaning of simple algebraic expressions.

The data obtained from the application aimed at determining students' PSoSL were analyzed with descriptive analysis, one of the qualitative data analysis techniques. Polya (1957) describes the problem-solving process as a four-step process: understanding the problem, devising a plan for solving the problem, carrying out the plan, and looking back/evaluating the solution. Gonzales (1998), on the other hand, suggested adding another step that he expressed as problem-posing or problem writing to Polya's problem-solving process. In this study, descriptive analysis was conducted using the five-step "Progressive Scoring Scale (PSS)" taken from Baki (2014) in line with the framework suggested by Polya (1957) and Gonzales (1998). The five steps of PSS (see Appendix B) were scored as 3,2,1, and 0, going from the highest to the lowest performance. The researchers made a new scoring to determine the students' PSoSL by adhering to the original PSS, which they used to analyze qualitative data. Accordingly, 3-point performance was defined as "very good," 2 as "good," 1 as "unsatisfactory," and 0 as 
"blank." They prepared two performance tasks (problems) to determine students' PSoSL. The opinions of an expert and a secondary school mathematics teacher were taken regarding the suitability of the problems in terms of content, level, and language to ensure content validity. The problems were then revised and conducted on three students as pilots. Afterward, the problems were finalized, and they were administered to the experimental group in 40 minutes. The guideline prepared to answer performance tasks is included in Appendix C.

\subsection{Data Analysis}

Quantitative and qualitative data obtained in the study were analyzed using appropriate analysis methods. Accordingly, the quantitative data were analyzed using the SPSS 22.0 package program. Wilcoxon Signed Rank Test, one of the non-parametric analysis techniques, was used to analyze the data. Wilcoxon Signed Rank Test was used to determine whether students' mathematical motivations differed with the teaching and practice/playing of "Mangala." Wilcoxon Signed Rank Test is primarily used in researches with a low sample size. This test replaces the t-test in cases where the score differences do not show normal distribution; the scores were obtained from the same subjects at different times (Büyüköztürk, 2006, 163). In this study, non-parametric statistical methods were used to analyze the data because the data did not show normal distribution, and the sample size was small. The correlation method was used to examine the relationship between students' PSoSL and mathematical motivation. The correlational analysis describes the relations between two or more variables (Büyüköztürk et al., 2010; Franenkel, Wallen, \& Hyun, 2012). In this study, this method was preferred because it was aimed to reveal the relationship between students' PSoSL and mathematical motivation.

The analysis of the data obtained from the application determining students' PSoSL was made with descriptive analysis, one of the qualitative data analysis techniques. In the descriptive analysis, the data is first described systematically and clearly according to the predetermined themes. These descriptions are then interpreted, and some results are reached through cause-effect relationships (Yıldırım \& Şimşek, 2018). In this study, the descriptive analysis has been performed in line with the framework suggested by Polya (1957) and Gonzales (1998), using the five-step "PPS" taken from Baki (2014); the scores of problem-solving steps were redefined as "very good, good, unsatisfactory and empty" by the researchers. Two researchers scored the problems given as performance tasks according to redefined levels, and the agreement between coders was calculated following the Miles and Huberman formula (1994). The agreement was found to be $85 \%$. The researchers re-evaluated the data together for the remaining $15 \%$, reached a consensus, and achieved $100 \%$ agreement. The levels of the answers given to problem-solving steps that researchers redefined by adhering to PPS to determine the students' problem-solving levels are as follows:

Very good: Understanding the problem completely, choosing the appropriate solution strategy, making the right solution, evaluating the solution logically, posing and solving a logical and solvable similar problem.

Good: Understanding the problem, choosing the appropriate solution strategy, solving the problem with some minor mistakes, verifying the result logically, and posing a problem by only changing the values in the problem.

Unsatisfactory: Failure to understand the problem, choosing only part of the appropriate solution strategy, solving the problem inappropriately and incorrectly, verifying the results partially, and posing a similar problem with logical error.

Empty: No effort has been made to understand the problem, no strategy has been chosen, the problem has not been solved, failure to know how to verify the result, and either the same problem has been posed, or no problem has been written.

The second sub-problem of the study, "What is the PSoSL of $6^{\text {th }}$-grade students who learned and played "Mangala" through distance education?" was addressed using these levels. Since an in-depth review of the PSoSL data is intended, a descriptive analysis was conducted using the qualitative approach, and the second sub-problem was addressed. Secondly, this data was treated quantitatively and used in correlation analysis to understand whether there is a statistically significant relationship between students' mathematical motivation and PSoSL. For the reliability of the study, two researchers scored PSoSL separately, and the agreement rate was calculated according to the Miles and Huberman formula (1994). The agreement rate was found to be $85 \%$. For the 15-point difference, the researchers made a re-evaluation together, reached a consensus, and achieved a $100 \%$ agreement. After scoring according to the determined levels, the SPSS 22.00 program was used to determine whether there is a statistically significant relationship between the students' PSoSL scores and the scores they got from MMS.

\subsection{Implementation Process}

This study was conducted online in the spring semester of the 2020-2021 academic year and lasted three weeks. 
The experimental group was the only group in the research, and the lessons continued following the existing Teaching Mathematics Program (MoNE, 2018) based on the constructivist approach. Students participated in all mathematics lessons throughout the process. Before starting the implementation, students were interviewed individually to understand whether they knew "Mangala." 7 students familiar with the game were excluded from the study, and the remaining 14 students were included. Students' mathematical motivation was measured by the Mathematical Motivation Scale (MMS), administered as the pre-test and post-test. Since the study was online, the MMS, consisting of 26 items, was prepared in Google Forms, the address link was sent to the students, and all students filled the scale. Students could answer the form only once; they were prevented from submitting more than one answer. The students were asked to write their names while filling the scale, and they were informed that the given answers would not be used in any other place than this scientific study. Students participated in the "Mangala" activity three days a week and the mathematics lessons in the weekly program during the implementation process. "Mangala" was taught to students by their mathematics teacher, who was also one of the researchers of this study. Then, students were left to play the game interactively from the "Mangala" game application that they downloaded to their phones or tablets. The activities carried out in the implementation process are given in Table 1.

Table 1. The activities carried out in the implementation process

\begin{tabular}{llll}
\hline Activities & $\mathbf{1}^{\text {st }}$ week & $\mathbf{2}^{\text {nd }}$ week & $\mathbf{3}^{\text {rd }}$ week \\
\hline Pre-test (MMS) & $\checkmark$ & & \\
Teaching "Mangala" & $\checkmark$ & $\checkmark$ & \\
Playing "Mangala" & $\checkmark$ & $\checkmark$ & $\checkmark$ \\
Post-test (MMS, PT) & & & $\checkmark$ \\
\hline
\end{tabular}

$\mathbf{1}^{\text {st }}$ week: Students were informed in detail about the process. MMS was administered as the pre-test. After collecting the pre-test data from all students, the implementation was started. Previously prepared slides and videos about "Mangala" were shown to the students. Then the researchers answered the students' questions by explaining the history, purpose, and rules of the game in detail. Each student downloaded the game called "Mancala" to their phone or computer, and for three days, students were left to play the game both in online classes and outside the class. Students were asked to share screens during the lesson. Each student was monitored at least once by their teachers and other students, and the mistakes made were corrected. Students played the game as much as they wanted without any limitations.

$\mathbf{2}^{\text {nd }}$ week: Considering the mistakes students made while playing "Mangala" in the first week, the details of the game were explained again. They were left to play the game for another three days.

$\mathbf{3}^{\text {rd }}$ week: Students continued to play "Mangala" for three days in the $3^{\text {rd }}$ week. The performance tasks prepared to determine students' PSoSL were reflected on the screen in the last lesson. All students were asked to answer the questions on the paper within the given time. They then took pictures of their answers and sent them to their teachers at the end of the lesson. All students' answer sheets were sent. Then, MMS was administered to students as the post-test, and the implementation process ended after collecting all answers.

\section{Results}

In this section, the findings obtained from the analyzes carried out to reveal the effect of "Mangala," which was played three days a week for three weeks outside the lessons in addition to the mathematics lessons instructed according to the current Teaching Mathematics Program (MoNE, 2018), on the mathematical motivation of students, whether there is a statistically significant relationship between their mathematical motivation and PSoSL and to determine the level of their PSoSL.

\subsection{Findings on the First Sub-Problem and Discussion}

The first sub-problem of the research was "Does "Mangala" taught by distance education create a statistically significant difference between pre and post-test MMS scores of 6th-grade students? The pre-test and post-test data obtained from MMS were analyzed using the Wilcoxon signed-rank test. Analysis results are given in Table 2. 
Table 2. Wilcoxon signed ranks test results for MMS scores

\begin{tabular}{llllll}
\hline Pre-Test- Post-Test & $\mathbf{n}$ & Mean Rank & Sum of Ranks & $\mathbf{z}$ & $\mathbf{p}$ \\
\hline Negative Rank & 0 & .00 & .00 & 3.30 & .001 \\
$\begin{array}{l}\text { Positive Rank } \\
\text { Same Rank }\end{array}$ & 14 & 7.50 & 105.00 & & \\
\hline
\end{tabular}

The analysis results show a significant difference between the pre and post-experiment scores of the students participating in the research $(\mathrm{z}=3.30, \mathrm{p}<.05)$. Regarding the mean rank and sum of the ranks, this observed difference is in favor of the post-test. According to this result, it can be said that "Mangala" has a significant effect on increasing students' mathematical motivation.

\subsection{Findings on the Second Sub-Problem}

The second sub-problem of the research was "What is the PSoSL of $6^{\text {th }}$-grade students playing "Mangala" taught by distance education?" In the analysis, the performance tasks were first scored regarding students' performance at each problem-solving step. Tables indicating the number of students at each level were prepared and interpreted. Then, direct quotations from the answers of the students were taken., PSoSL is determined according to the performance scores obtained from problem-solving steps; they are shown together with the number of students in Table 3.

Table 3. Students' PSoSL and total performance scores

\begin{tabular}{|c|c|c|c|c|c|c|c|c|c|}
\hline & \multirow[b]{3}{*}{$\begin{array}{l}\text { PSoSL and } \\
\text { Performance Scores }\end{array}$} & \multirow{2}{*}{\multicolumn{4}{|c|}{$\begin{array}{l}\text { Performance Task } 1 \\
\text { Number of students } \\
\text { (total performance scores) }\end{array}$}} & \multirow{2}{*}{\multicolumn{4}{|c|}{$\begin{array}{l}\text { Performance Task } 2 \\
\text { Number of students } \\
\text { (total performance score) }\end{array}$}} \\
\hline & & & & & & & & & \\
\hline & & $\begin{array}{l}\text { Very } \\
\text { good } \\
(3) \\
\end{array}$ & $\begin{array}{l}\text { Good } \\
\text { (2) }\end{array}$ & $\begin{array}{l}\text { Unsatisfactory } \\
\text { (1) }\end{array}$ & $\begin{array}{l}\text { Empty } \\
(0)\end{array}$ & $\begin{array}{l}\text { Very } \\
\text { good } \\
(3) \\
\end{array}$ & $\begin{array}{l}\text { Good } \\
\text { (2) }\end{array}$ & $\begin{array}{l}\text { Unsatisfactory } \\
\text { (1) }\end{array}$ & $\begin{array}{l}\text { Empty } \\
(0)\end{array}$ \\
\hline $\begin{array}{l}\text { Problem-solving } \\
\text { steps }\end{array}$ & Criteria & & & & & & & & \\
\hline $\begin{array}{l}\text { Understanding } \\
\text { the problem }\end{array}$ & $\begin{array}{l}\text { Expressing the problem } \\
\text { in own words }\end{array}$ & $9(27)$ & $2(4)$ & - & $3(0)$ & $9(27)$ & $1(2)$ & $1(1)$ & $3(0)$ \\
\hline \multirow[t]{3}{*}{ Devising a plan } & $\begin{array}{l}\text { Writing what is given } \\
\text { and asked in the } \\
\text { problem }\end{array}$ & $9(27)$ & 2(4) & - & $3(0)$ & $10(30)$ & $1(2)$ & - & $3(0)$ \\
\hline & Modeling the problem & $5(15)$ & 2(4) & $2(2)$ & $5(0)$ & $4(12)$ & $3(6)$ & 2(2) & $5(0)$ \\
\hline & $\begin{array}{l}\text { Identifying the solution } \\
\text { of the problem }\end{array}$ & $5(15)$ & $3(6)$ & $1(1)$ & $5(0)$ & $5(15)$ & $2(4)$ & 2(2) & $5(0)$ \\
\hline $\begin{array}{l}\text { Carrying out } \\
\text { the plan }\end{array}$ & $\begin{array}{l}\text { Solving the problem by } \\
\text { following the rules }\end{array}$ & $12(36)$ & - & - & $2(0)$ & $12(36)$ & - & - & $2(0)$ \\
\hline \multirow[t]{2}{*}{ Looking back } & $\begin{array}{l}\text { Checking the } \\
\text { correctness of the result }\end{array}$ & $12(36)$ & - & - & $2(0)$ & $11(33)$ & - & $1(1)$ & $2(0)$ \\
\hline & $\begin{array}{l}\text { Interpreting the result } \\
\text { and drawing conclusions } \\
\text { from the problem }\end{array}$ & $10(30)$ & - & 2(4) & $2(0)$ & $11(33)$ & $1(2)$ & - & $2(0)$ \\
\hline $\begin{array}{l}\text { Suggesting/posing } \\
\text { a similar problem }\end{array}$ & $\begin{array}{l}\text { Posing a similar } \\
\text { problem }\end{array}$ & $8(24)$ & 2(4) & - & $4(0)$ & $7(21)$ & $3(6)$ & - & $4(0)$ \\
\hline and solving it & $\begin{array}{l}\text { Solving the posed } \\
\text { similar problem }\end{array}$ & $8(24)$ & 2(4) & - & $4(0)$ & $6(18)$ & $4(4)$ & - & $4(0)$ \\
\hline
\end{tabular}

-: There are no answers in the relevant criterion.

Regarding Table 3, some students failed to answer the questions in the given performance tasks at each problem-solving step. The students who could not answer failed to develop a strategy for solving the problems in both performance tasks, and they were not successful in posing and solving a similar problem. Again, from Table 3 , the number of students who responded unsatisfactorily to the performance tasks is relatively low. These students have difficulties creating a strategy for the problem, posing a similar problem, and solving it. As shown in Table 3, most of the students produced very good and good solutions to the problems. An interesting result 
emerging from the "very good" performance level of Table 3 is that the number of students who answered solving the problem and checking the correctness of the solution steps was higher than the number of students who answered understanding the problem and devising a plan steps. The reason behind it might be that when students encounter a problem, they want to solve it by directly focusing on the solution. In the one-to-one interviews, these students expressed the problems with their own sentences and explained their solution strategies. This fact can also be seen in direct quotations from students (see Figure 2).

Table 4 was created to understand better the data obtained from this research. Firstly, the minimum and maximum scores that can be achieved from each step were calculated. Accordingly, the maximum possible score of each performance level is determined by multiplying "number of problem-solving steps $\mathrm{x}$ performance score $\mathrm{x}$ number of students." For example, the highest performance score that can be achieved for the "Very good" level is calculated as follows. Problem-solving consists of 5 steps. The score of very good is 3 . The number of students in the study is 14 . Therefore, the highest performance score that can be obtained for the "Very good" level is $5 \times 3 \times 14=210$. In Table 3, each problem-solving step is defined with different numbers of criteria. In Table 4, the total score of the step is divided by the number of criteria to get a single score. Since the maximum score of the "blank" level is 0 , it is not included in Table 4.

Table 4. Averages of students' total performance scores and PSoSL

\begin{tabular}{|c|c|c|c|c|c|c|}
\hline \multirow{3}{*}{$\begin{array}{l}\text { Problem-solving } \\
\text { steps }\end{array}$} & \multicolumn{6}{|c|}{$\begin{array}{l}0 \leq \text { performance score of very good level } \leq 210, \\
0 \leq \text { performance score of good level } \leq 140, \\
0 \leq \text { performance score of unsatisfactory level } \leq 70\end{array}$} \\
\hline & \multicolumn{3}{|c|}{$\begin{array}{l}\text { PT1 and PSoSL } \\
\text { Averages of performance scores for each } \\
\text { level of each step }\end{array}$} & \multicolumn{3}{|c|}{$\begin{array}{l}\text { PT2 and PSoSL } \\
\text { Averages of performance scores for } \\
\text { each level of each step }\end{array}$} \\
\hline & Very good (3) & Good (2) & Unsatisfactory (1) & Very good (3) & Good (2) & Unsatisfactory (1) \\
\hline $\begin{array}{l}\text { Understanding } \\
\text { the problem }\end{array}$ & $27: 1=27$ & $4: 1=4$ & - & $27: 1=27$ & $2: 1=2$ & $1: 1=1$ \\
\hline Devising a plan & $(27+15+15): 3=19$ & $(4+4+6): 3=4,66$ & $(2+1): 2=1,5$ & $(10+14+5): 3=6,33$ & $(1+3+2): 3=2$ & $(2+2): 2=2$ \\
\hline $\begin{array}{l}\text { Carrying out } \\
\text { the plan }\end{array}$ & $36: 1=36$ & - & - & $36: 1=36$ & - & - \\
\hline Looking back & $(30+36): 2=33$ & - & $4: 1=4$ & $(33+33): 2=33$ & $2: 1=2$ & - \\
\hline $\begin{array}{l}\text { Posing\&solving } \\
\text { a similar problem }\end{array}$ & $(24+24): 2=24$ & $(4+4): 2=4$ & - & $(21+18): 2)=19,5$ & $(6+4): 2=5$ & - \\
\hline $\begin{array}{l}\text { Total Perfoemence } \\
\text { Score }\end{array}$ & 139 & 12,66 & 5,5 & 121,83 & 11 & 3 \\
\hline
\end{tabular}

Since there is more than one criterion in the "devising a plan," looking back," and "posing\&solving similar problem" steps of problem-solving, the averages of the scores achieved at these steps are shown in Table 4. The scores obtained from each performance task at each level can be seen in Table 4. Accordingly, most of the students gave very good and good answers. Two performance tasks were given to the students to determine their PSoSL. The average performance task scores were calculated, the ratio of total performance scores to the maximum possible score was taken, and Table 5 was created.

Table 5. Average scores that students get from performance tasks and their ratio to the maximum possible score

\begin{tabular}{llll}
\hline PSoSL & Very Good & Good & Unsatisfactory \\
\hline (PT1+PT2):2=average score & 130.41 & 11.83 & 4.25 \\
$\%$ & 62.1 & 8.45 & 6.07 \\
\hline
\end{tabular}

Regarding Table 5, the majority of the students gave very good answers. It can be said that the students achieved significant success by getting $62.1 \%$ of 210 , which is the highest performance score that can be obtained from the "very good" level.

Direct quotations from students' answers for each problem-solving step are shown in Figures 2, 3, 4, 5, 6, 7, and 8.

In Figure 2, students answered the question "express the problem in your own words" with expressions such as 
"Find 8 more than 3 times", "short edge," and "We will find an algebraic expression in the problem and calculate it with the given values." These students' answers show that they failed to fully express the problems in their own words and focused on devising a plan. However, in the interview with these two students who gave these answers, they expressed the problem verbally in their own words; therefore, their performance was evaluated as good.

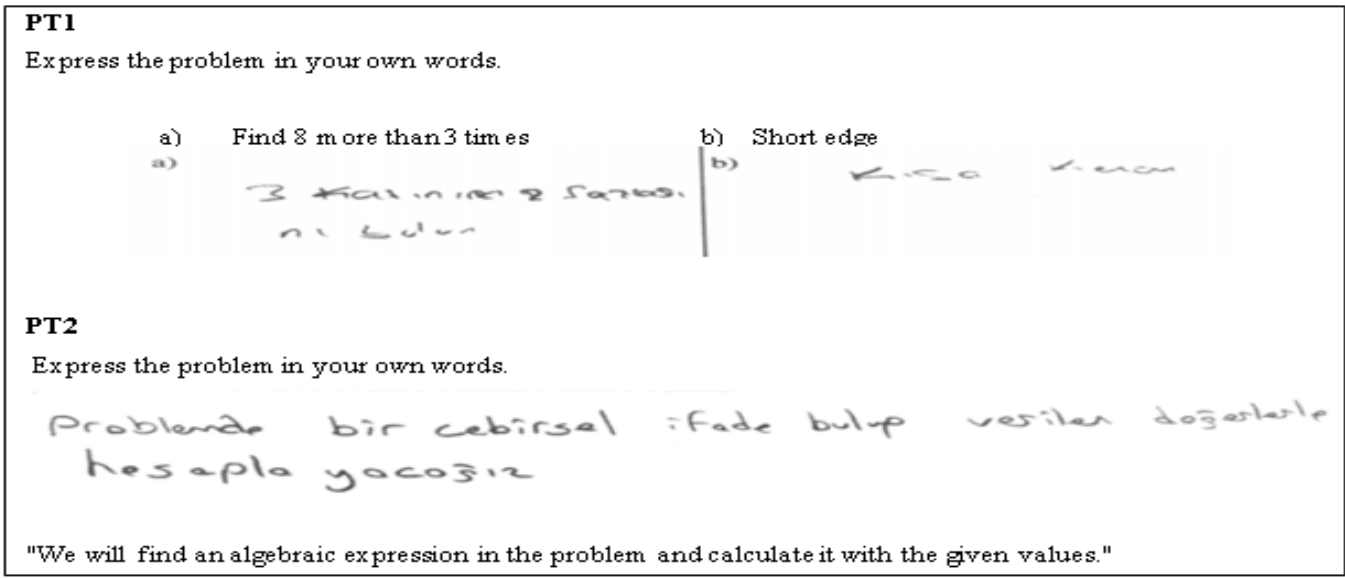

Figure 2. Student answers for the "understanding the problem" step evaluated as "good."

In Figure 3, the student's answers at "devising a plan" step were "asked $=$ find the algebraic expressions expressing the short side., given: all students attend the lesson." and "asked $=$ write the algebraic expressions verbally. given $=$ short side, $x$ long side $3 x+5 "$. The student's performance levels in PT1 and PT2 were evaluated as unsatisfactory because one student could not write what was given and asked, and the other did not make any explanations.

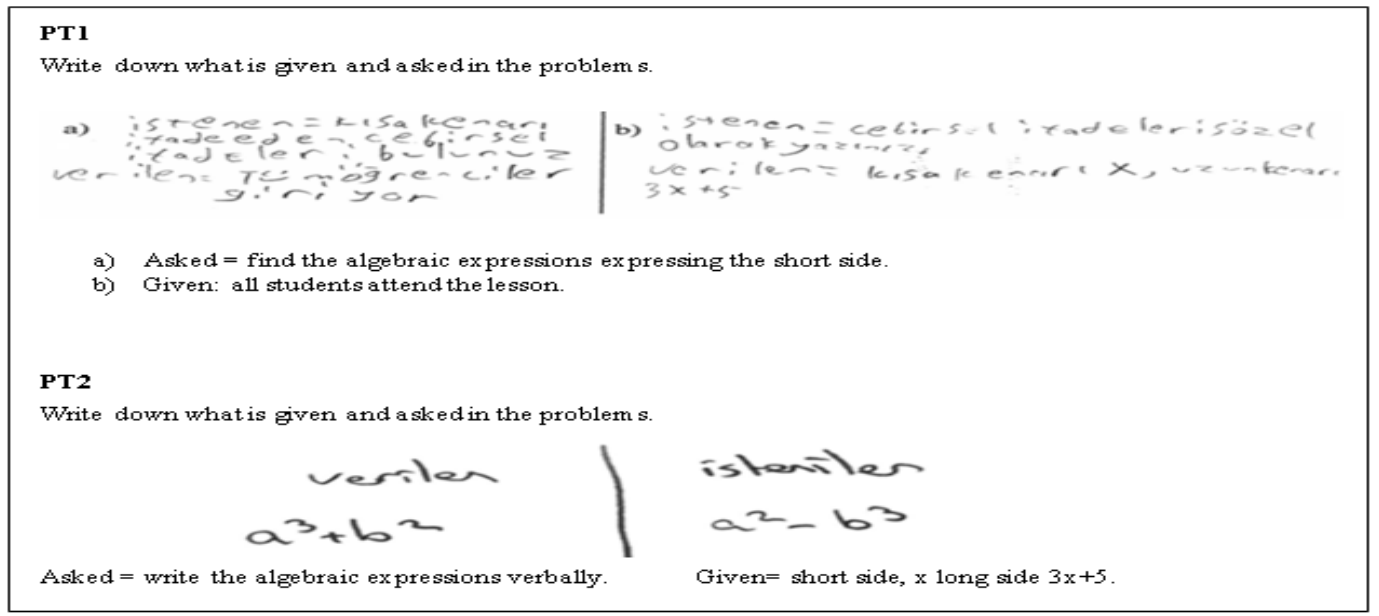

Figure 3. Student answers for the "devising a plan" step evaluated as good and unsatisfactory

In Figure 4, the students were asked to make mathematical modeling for the "devising a plan" step of problem-solving. However, the student who answered PT1 could not model the problem correctly because he failed to properly use the number, unknown, and variable concepts. Therefore, this student's answer was evaluated as unsatisfactory. The student who answered PT2, on the other hand, was evaluated as very good because he did the modeling correctly. 


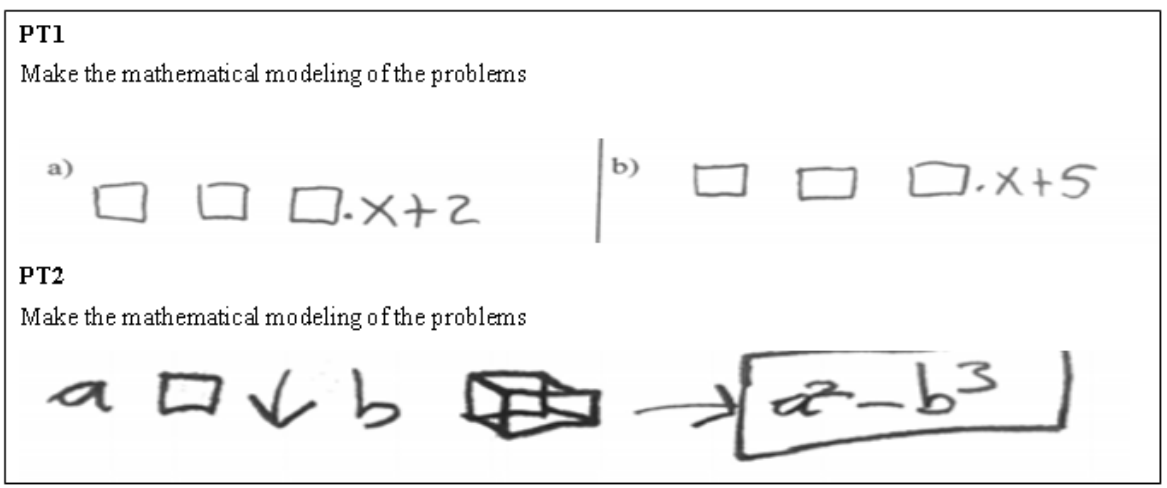

Figure 4. Student answers for the "devising a plan" step evaluated as unsatisfactory and very good

In Figure 5, students who answered PT1 and PT2 solved the problems correctly. Therefore, the answers of these students were evaluated as very good.

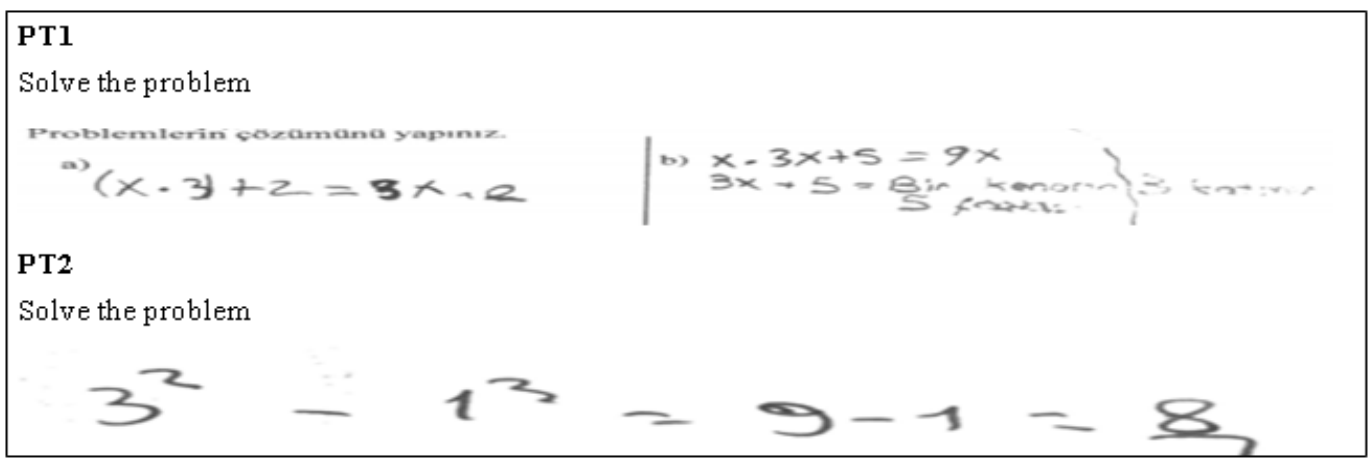

Figure 5. Student answers for the "carrying out the plan" step evaluated as very good

In Figure 6, the student who answered PT1 lacked knowledge about the order of operations and therefore could not check the correctness of the solution of the given problem. This student's answer was evaluated as unsatisfactory. The student who answered PT2 in Figure 6 did make no explanation while checking the correctness of the solution and solved the problem again: therefore, this student's answer was evaluated as good.

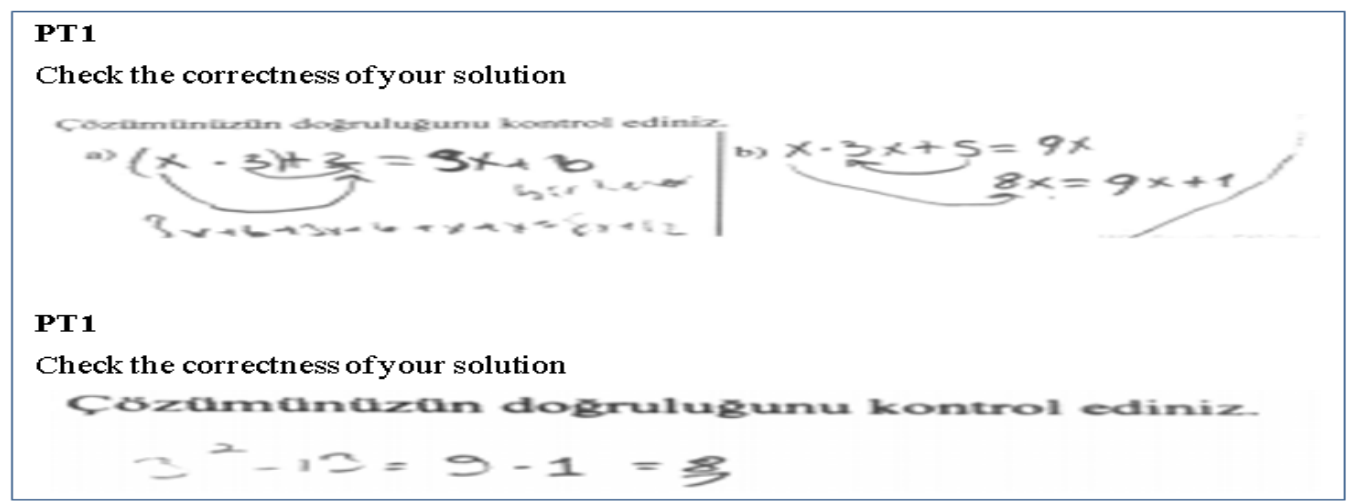

Figure 6. Student answers to the "looking back" step evaluated as unsatisfactory and good

The answers of the students who were asked to pose and solve a similar problem in PT1 and PT2 are shown in Figure 7. The student could not pose a problem similar to PT1 and therefore could not solve it; on the other hand, another student who answered PT2 posed a similar problem and solved it. 


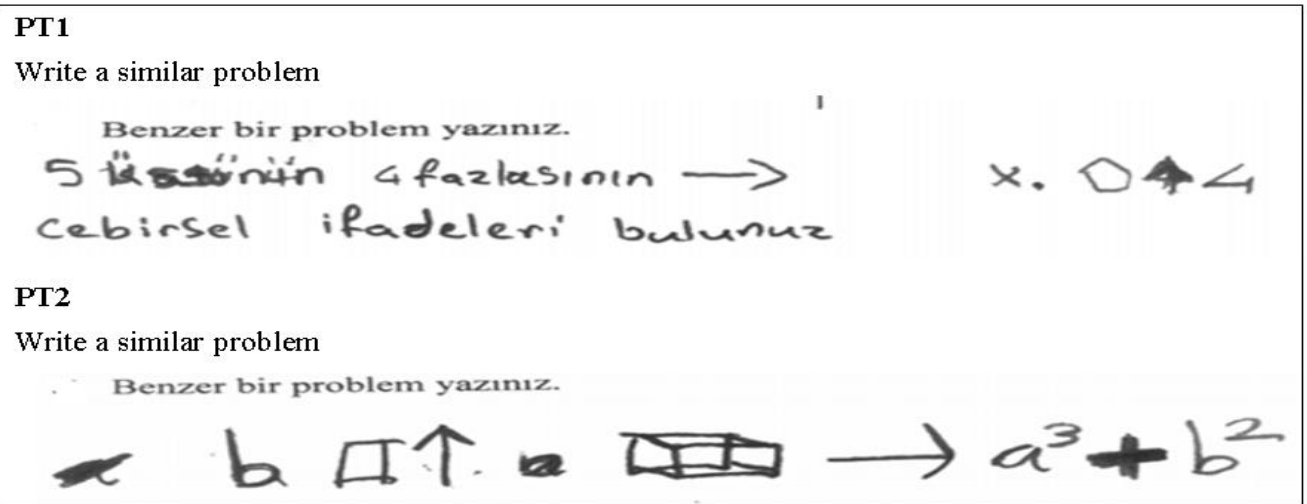

Figure 7. Student answers to the "suggesting/posing and solving a similar problem" step evaluated as unsatisfactory and good

\subsection{Findings on the Third Sub-Problem}

The third sub-problem of the study was expressed as "Is there a statistically significant relationship between PSoSL and the mathematical motivations of $6^{\text {th }}$-grade students?"

Correlation analysis was conducted to determine whether there is a statistically significant relationship between students' scores from MMS and PSoSL. Non-parametric tests were used because the sample size was small, and the data did not show a normal distribution. Spearman-Brown Rank Differences method was used, and Spearman's rank correlation coefficient was calculated to explain the relationship between the two variables. Table 6 contains the findings obtained from the correlation analysis.

Table 6. The Results of Spearman Correlation Analysis between MMS and PSoSL

\begin{tabular}{clll}
\hline Variables & & MMS & PSoSL \\
\hline & $\mathrm{r}$ & 1 & $.794^{*}$ \\
MMS & $\mathrm{p}$ & & .001 \\
& $\mathrm{~N}$ & 14 & 14 \\
& $\mathrm{r}$ & $.794^{*}$ & 1 \\
PSoSL & $\mathrm{p}$ & .001 & \\
& $\mathrm{~N}$ & 14 & 14
\end{tabular}

*: Correlation is significant at 0.01 level (2-tailed). PSoSL: Problem-solving skill level, MMS: Mathematical Motivation Scale,

r: Spearman's Correlation Coefficient

Regarding Table 6, there is a strong, positive, and significant relationship between MMS and PSoSL ( $\mathrm{r}=.794$, $\mathrm{p}<.05$ ). Based on this result, it can be said that there is a high level, positive and significant relationship between students' mathematical motivation and PSoSL. In this study, which has been conducted with a single-group quasi-experimental design, it can be said that students' learning and playing "Mangala" through distance education increased their mathematical motivation based on the findings of the first sub-problem. In addition, it seems possible to state that the increase in students' mathematical motivation was positively reflected in their PSoSL.

\section{Discussion and Conclusion}

This study investigated the effect of teaching and playing "Mangala" through distance education on $6^{\text {th }}$-grade students' mathematical motivations and PSoSL and the relationship between them. As a result, a significant difference was found between students' pre- and post-experiment MMS scores. Based on this result, it can be said that "Mangala" increased the mathematical motivation of $6^{\text {th }}$-grade students.

This study's second sub-problem was set as examining PSoSL of $6^{\text {th }}$-grade students who played "Mangala," taught through distance education. The results of data analysis showed that the number of students who answered the performance tasks (prepared to determine students' PSoSL) as unsatisfactory is relatively low. Besides, these students had difficulties devising a plan for the solution and posing and solving a similar problem. On the other 
hand, most of the students gave very good and good answers to the performance tasks. They were able to solve the problems by applying their own plans and strategies. The majority of the students achieved significant success by getting $62.1 \%$ of the 210 points, the highest score that can be achieved for the very good level. On the other hand (see Table 3), an interesting result emerged in the very good performance level: the number of students who answered solving the problem and checking the correctness of the solution steps was higher than the number of students who answered understanding the problem and devising a plan steps. It may be because students tend to solve the problem by directly focusing on the solution when faced with a problem. In one-to-one interviews with these students, they expressed the problems with their own sentences and explained their solution strategies. It is recommended to conduct qualitative studies investigating the reasons for this situation.

The study results of Karayol and Temel (2018) on the game and PSoSL were similar to this study. Karayol and Temel (2018) reported that structured games are effective in reaching the target. Similarly, Kurbal (2015) reported that intelligence games improved the problem-solving strategies of $6^{\text {th }}$-grade students and that the students found the games entertaining and valuable. According to Zaslavsky (1979), "Mangala" contributes to the development of PSoSL (as cited in Ismael, 2001). Zaslavsky's (1979) view supports the results of this study.

The definitions of the game (Biriktirir, 2008; Demirel, 2006; Öztürk, 2007) reveal that the game is an active learning process, effective in the physical, cognitive, emotional, and social development of the child and children take part willingly and voluntarily. In learning with games, games appeal to more than one sense organ and encourage communication between students. Therefore, students can produce many ideas and act higher (Seo, 2003, cited in Kaya \& Elgün, 2015). Studies involving teaching with games have increased student achievement, motivation, and performance (Aksoy, 2014; Kaya \& Elgün, 2015; Randel, Morris, Wetzel, \& Whitehill, 1992; Romine, 2004, Usta et al., 2018). According to Randel et al. (1992), an entertaining classroom environment increases students' motivation throughout the course, strengthens their performance, and helps them understand mathematical knowledge better. The results of this study, in which Mangala teaching increased the mathematical motivation of $6^{\text {th }}$-grade students, and the results of Randel et al.'s (1992) and Romine's (2004) are similar in this context. Schweinle, Meyer, and Turner (2006) found that the effective feedback of the teacher, explaining the concepts, social relations, and cooperation, supporting student autonomy, and focusing on the learning process increased student motivation.

As a result of the correlation analysis performed to answer the third sub-problem of the study, a strong, positive, and significant relationship was found between MMS and PSoSL $(r=.794, p<.05)$. According to this result, it can be said that there is a high level, positive and significant relationship between students' mathematical motivation and PSoSL. Students' learning and playing "Mangala" through distance education increased their mathematical motivation, and this result is significantly, positively, and highly correlated with their PSoSL.

This study has shown that using "Mangala" in the teaching process positively affects the mathematical motivation of $6^{\text {th }}$ - grade students. The intrinsic characteristics of "Mangala," such as struggle, belonging to a group, the will to win, and the game format, may have been effective in the emergence of this result. It is possible to offer more active and entertaining learning environments for students by using "Mangala."

\section{Suggestions}

During the current Covid-19 epidemic, teaching via distance education has become inevitable. Mathematics lessons, which students perceive as abstract and complex, created considerable stress on most students, especially in this period, due to the accumulation of different reasons. This study showed that "Mangala" effectively increased students' mathematical motivation in the distance education process. In this context, it can be suggested to play "Mangala" and similar games in mathematics classes to increase the mathematical motivation of students, especially in periods similar to the pandemic we live in. The 3-week period was one of the limitations of the study. For this reason, it is recommended for future research to keep the implementation process longer and increase the number of participants. It is suggested to conduct a qualitative analysis for the interesting results of this research that emerged from the measurement of PSoSL. In addition, it is suggested to carry out this study at different grade levels and use experimental designs with control groups.

\section{Acknowledgement}

This article is an expanded version of the oral presentation presented at the "14th National Science and Mathematics Education Congress (14. Ulusal Fen Bilimleri ve Matematik Eğitimi Kongresi)" held at Mehmet Akif Ersoy University on 19-21 May 2021.

\section{References}

Abonyi, O. S., Maduagwuna, N. M., \& Ugama, J. O. (2014). Effects of Mathematical game on students 
achievement in quadratic expressions. International Journal of Scientific and Engineering Research, 5(6), 678-684.

Adler, R. W., Milne, M. J., \& Stablein, R. (2001). Situated motivation: An empirical test in an accounting course. Canadian Journal of Administrative Sciences, 18(2), 101-115. https://doi.org/10.1111/j.1936-4490.2001.tb00248.x

Akbaba, S. (2006). Eğitimde motivasyon [Motivation in education]. Journal of Kazım Karabekir Education Faculty, 13, 343-361.

Aksoy, N. C. (2014). Effects of digital game-based mathematics teaching on 6th grades students' achievement, motivation, attitude and self-efficacy (Doctoral dissertation). Gazi University Graduate School of Educational Sciences, Ankara.

Baki, A. (2014). Mathematics education from theory to practice. Letter Education Publishing.

Bragg, L. (2006). Students impressions of the value of games for the learning of mathematics. In Proceedings of the 30th conference of the international group for the psychology of mathematics education. International Group for the Psychology of Mathematics Education. pp. 217-224.

Biriktirir, A. (2008). The effect of the game method on achievement in teaching mathematics lesson geometry subjects in fifth grade of primary school (Unpublished master's thesis). Selçuk University, Konya.

Büyüköztürk, Ş. (2006). Sosyal bilimler için veri analizi el kitabı [Manual of data analysis for social sciences]. Ankara: Pegem Academy.

Büyüköztürk, Ş., Çakmak, E., K., Akgün, Ö. E., Karadeniz, Ş., \& Demirel, F. (2010). Scientific research methods (6th ed). Ankara: Pegem Academy.

Demirel, Ö. (2006). Öğretme sanatı [The art of learning]. Ankara: Pegem Academy.

Dinçer, S. (2006, February). Bilgisayar destekli ĕgitim ve uzaktan eğitime genel bir bakış [An overview of computer assisted education and distance education]. Eğitim ve Bilişim Sempozyumu.

Erdoğan, A., Eryılmaz Çevirgen, A., \& Atasay, M. (2017). Games and mathematics teaching: a classification of strategic brain games. Usak University Journal of Social Sciences, 10/Special Issue, 2, 287-311.

Ersoy, E., \& Başer, N. (2010). The effect of problem based learning process on student motivation. International Periodical for the Languages, Literature and History of Turkish or Turkic, 5(4), 336-358. https://doi.org/10.7827/TurkishStudies.1766

Franenkel, J. R., Wallen, N. E., \& Hyun, H. H. (2012). How to design and evaluate research in education (8th ed). New York: McGraw-Hill.

Garris, R., Ahlers, R., \& Driskell, J. E. (2002) Games, motivation, and learning: A research and practice model. Simulation \& Gaming, 33(4), 441-467. https://doi.org/10.1177/1046878102238607

Glynn, S. M., Aultman, L. P., \& Owens, A. M. (2005). Motivation to learn in general education programs. The Journal of General Education, 54(2), 150-170. https://doi.org/10.1353/jge.2005.0021

Gonzales, N. A. (1998). A blueprint for problem posing. School Science and Mathematics, 98(8), $448-456$. https://doi.org/10.1111/j.1949-8594.1998.tb17437.x

Herges, R. M., Duffield, S., Martin, W., \& Wageman, J. (2017). Motivation and achievement of middle school mathematics students. The Mathematics Educator, 26(1), 83-106.

Holmberg, B. (1997). Distance education theory again. Open Learning, 12(1), 31-39. https://doi.org/10.1080/0268051970120105

Ismael, A. (2001). An ethnomathematical study of tchadjl about a mancala type board game played in mozambique and possibilities fot its use in mathematics education. University of the Witwatersrand, Johannesburg.

İspir, O. A., Ay, Z. S., \& Sayg1, E. (2011). High achiever students' self regulated learning strategies, motivation towards mathematics, and their thinking styles. Education and Science, 36(162), 235-246.

İşman, A. (2011). Uzaktan ĕgitim [Distance learning] (Improved 4th ed). Pegem Academy, Ankara.

Karasar, N. (2003). Bilimsel araştırma yöntemi [Scientific research method]. Ankara. Nobel Publication Distribution.

Karataş, İ., \& Güven, B. (2003). Problem çözme davranışlarının değerlendirilmesinde kullanılan yöntemler: 
klinik mülakatın potansiyeli. İlkögretim-online e-dergi, 2(2), 2-9. Retrieved from http://www.ilkogretim-online.org.tr

Karayol, S., \& Temel, Z. F. (2018). An examination of 5-year-old children's problem-solving skills through playbased activities. Cumhuriyet International Journal of Education, 7(2), 143-174. https://doi.org/10.30703/cije.393747

Kaya, S., \& Elgün, A. (2015). The influence of instructional games in science teaching on primary students' achievement. Kastamonu Education Journal, 23(1), 329-342.

Kesici, A. (2018). Examining the impact of mathematics motivation on mathematics achievement in high school students. Ondokuz Mayls University Journal of Education Faculty, 37(2), 177-194.

Kurbal, M. Ç. (2015). An investigation of sixth grade students' problem solving strategles and underlying reasoning in the context of a course on general puzzles and games (Unpublished master's thesis). Graduate School of Social Sciences, METU, Ankara.

Küçükyıldız, A. (2020). Küçürme Mangala/Türk Zeka Oyunları:1, Delta Kültür Yayınevi.

Lee, Y. L. (2009). Enhancement of fractions from playing a game. In Crossing divides: MERGA 32: Proceedings of the 32nd Annual Conference of the Mathematics. pp. 323-330.

Lou, Y., Abrami, P., \& D'Apollonia, S. (2001) Small group and individual learning with technology: a metaanalysis. Review of Educational Research, 71(3), 449-52. https://doi.org/10.3102/00346543071003449

Lumsden, L. (1994). Student motivation to learn. ERIC Digest, 92, 1-7.

Martin, A. J. (2001). The Student Motivation Scale: A tool for measuring and enhancing motivation. Australian Journal of Guidance and Counselling, 11, 1-20. https://doi.org/10.1017/S1037291100004301

Miles, M. B., \& Huberman, A. M. (1994). Qualitative data analysis: An expanded sourcebook (2nd ed). California: SAGE Publications.

MoNE. (2018). Teaching mathematics (1, 2, 3, 4, 5, 6, 7 and $8^{\text {th }}$ grades) program. Ankara: Ministry of National Education, Board of Education.

Moenikia, M. V., \& Zahed, B. (2010). A study of simple and multiple relations between mathematics attitude, academic motivation and intelligence quotient with mathematics achievement. Procedia Social and Behavioral Sciences, 2, 1537-1542. https://doi.org/10.1016/j.sbspro.2010.03.231

Moore, M. G. (1989). Editorial: Three types of interaction. American Journal of Distance Education, 3(2), 1-7. https://doi.org/10.1080/08923648909526659

Musesti, A., Paolini, M. \& Reale, C. (2015). An optimal bound on the number of moves for open mancala. Discrete mathematics, 338, 1827-1844. https://doi.org/10.1016/j.disc.2015.04.013

National Center for Education Statistics (NCES). (2008). Distance education at degree granting postsecondary institutions: 2006-07. Retrieved from https://nces.ed.gov/pubs2009/2009044.pdf

Özdemir, O., \& Öner, İ. E. (2015). The effects of simulations and animations on students' motivation in a computer cours. Participatory Educational Research (PER), Special Issue II, 53-59. https://doi.org/10.17275/per.15.spi.2.7

Özkaya, A. (2021). Strateji oyunları [Strategy games]. In M. Taştepe \& N. C. Aksoy (Eds.), Oyun ve matematik eğitimi [Games and math education] (pp. 213-235). Ankara: Nobel Akademy.

Öztürk, D. (2007). A study of the effects of computer games on children's cognitive and affective development. (Unpublished master's thesis). Dokuz Eylul University Institute of Educational Sciences, İzmir.

Palmer, D. (2007). What is the best way to motivate students in science? Teaching Science: The Journal of the Australian Science Teachers, 53(1), 38-45.

Pintér, K. (2010). Creating games from mathematical problems. PRIMUS: Problems, Resources, and Issues in Mathematics Undergraduate Studies, 21(1), 73-90. https://doi.org/10.1080/10511970902889919

Polya, G. (1957). How to solve it. Princeton University: Princeton, NJ, 1957.

Randel, J., Morris, B., Wetzel, C., \& Whitehill, B. (1992). The effectiveness of games for educational purposes: A review of recent research. Simulation \& Gaming, 23(3), 261-276. https://doi.org/10.1177/1046878192233001

Rifandi, R. (2013). Improving students' motivation in learning mathematics by using contextual teaching 
strategies. pp. 1-9. Retrieved from https://www.researchgate.net/publication/236271785

Romine, X. (2004). Using games in the classroom to enhance motivation, participation, and retention: A pretest and post-test evaluation, Culminating Experience Action Research Projects, 5(Spring), 283-295.

Rondina, J. Q., \& Roble, D. B. (2019). Game-based design mathematics activities and students' learning gains. The Turkish Online Journal of Design, Art and Communication - TOJDAC, 9(1), 1-7. https://doi.org/10.7456/10901100/001

Rosas, R., Nussbaum, M., Cumsille, P., Marianov, V., Correa, M., ... Salinas, M. (2003) Beyond Nintendo: design and assessment of educational video games for first and second grade students. Computer \& Education, 40(1), 71-94. https://doi.org/10.1016/S0360-1315(02)00099-4

Sayg, E., \& Alkaş Ulusoy, Ç. (2019). Views of the pre-service elementary mathematics teachers about memory games and contribution of memory games to mathematics teaching. Bolu Abant izzet Baysal University Journal of Faculty of Education, 19(1), 331-345. https://doi.org/10.17240/aibuefd.2019.19.43815-446550

Seah, W. T., \& Bishop, A. J. (2000). Values in mathematics textbooks: A view through two Australasian regions. Paper Presented at the Annual Meeting of the American Educational Research Association, New Orleans, LA.

Schweinle, A., Meyer, D., \& Turner, J. (2006). Striking the right balance: student'motivation an affect in elementary mathematics. Journal of Educational Research, 99, 271-293. https://doi.org/10.3200/JOER.99.5.271-294

Silva, J. N. (2011). On mathematical games. BSHM Bulletin: Journal of the British Society for the History of Mathematics, 26(2), 80-104. https://doi.org/10.1080/17498430.2011.560511

Simonson, M., Smaldino, S. E., Albright, M., \& Zvacek, S. (2012). Teaching and learning at adistance: Foundations of distance education. Boston: Pearson Education, Inc.

Swings, S., \& Peterson, P. (1988). Elaborative and integrative thought processes in mathematics learning. Journal of Educational Psychology, 80(1), 54-66. https://doi.org/10.1037/0022-0663.80.1.54

Taclay, R. J. (2013). Effects of mathematical games strategy on the achievement of students in high school geometry. JPAIR Institutional Research, 1(1), 82-96. https://doi.org/10.7719/irj.v1i1.206

Tuan, H. L., Chin, C. C., \& Shieh, S. H. (2005). The development of a questionnaire to measure students ${ }^{\text {ee }}$ motivation towards science learning. International Journal of Science Education, 27(6), 639-654. https://doi.org/10.1080/0950069042000323737

Uğurel, I., \& Moralı, S. (2008). The interaction of mathematics \& game. Gazi University Journal of Gazi Educational Faculty, 28(3), 75-98.

Uluışık, Y. P. (2018). An assessment of the Mangala game. TURAN-SAM, 10(39), 173-186.

Usta, N., Işık, A. D., Taş, F., Gülay, G., Şahan, G., Genç, S., Diril, F., Demir, Ö., \& Küçük, K. (2018). The effect of teaching mathematics with games on the mathematics achievement of secondary school 7th grade students. Elementary Education Online, 17(4). 1972-1987. https://doi.org/10.17051/ilkonline.2019.506917

Usta, N., \& Çağan, B. (2020). Impact of teaching topics of equality and equation with scenarios on 7th graders' mathematical achievement and mathematical motivation. Educational Research and Reviews, 15(7), 354-369. https://doi.org/10.5897/ERR2020.3962

Üzel, D., Uyangör, N., Hasar, B., \& Çakır, Ö. (2018). Developing the motivation scale for the math class. Journal of Social and Humanities Sciences Research, 5(18), 378-386. https://doi.org/10.26450/jshsr.341

Yaman, S., \& Dede, Y. (2007). Examination of motivation level of students towards science and mathematics by some variables. Educational Administration: Theory and Practice, 52, 615-638.

Yıldırım, A., \& Şimşek H. (2018). Qualitative research methods in the social sciences (11th ed). Ankara: Seçkin Publication. 


\section{Appendix}

Appendix A.

Performance tasks prepared to determine PSoSL

\section{DISTANCE LEARNING}

6'A class students are taught their courses online during the distance education process. Due to the system's intensity, some studentsm ay have problem sconnecting to the lesson on the same day. The connection status of a class of 12 people to two different lessons on the same day is given below.

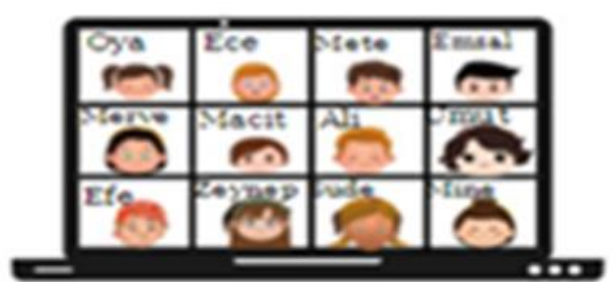

Figure 1: First lesson

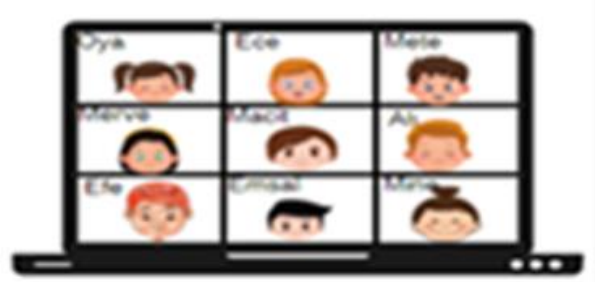

Figure 2: Secondlesson

While all students attended the first lesson, three students had problem s connecting to the second one, and only nine students attended the second.

a) Students attending the first lesson see each other on the screen. Under this condition, regarding the im age on the screen of a student attending the first lesson, if the length of the long side is 2 more than 3 tim es the length of the short side, write the algebraic expression that gives the length of the long side of the screen im age.

b) Students attendingthe secondlesson see each other on the screen. Under this condition, regarding the im age on the screen of a student attendingthe secondlesson, if the length of the short side is $x$ units and the length of the long side is $3 x+5$ units, verbally express the algebraic expression that gives the length of the long side of the screen im age.

\section{RE SFEBE CONTEST}

Bügra teacher is playing the resfebe game with her 6 th-grade students. The definition and explanations of the resfebe game are given below.

Resfebe is an intelligence gam e based on finding an ex pression by com bining letters, numbers, and pictures. küp=cube, artm $a=$ increase, kare $=$ square

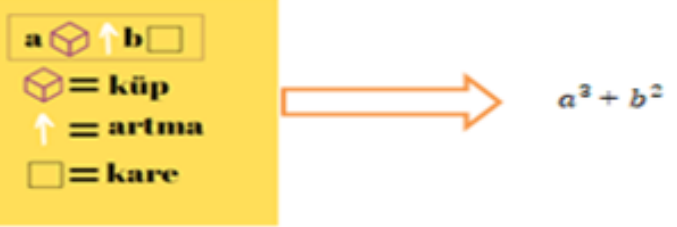

Bügra teacher wrote the following resfebe on the board.

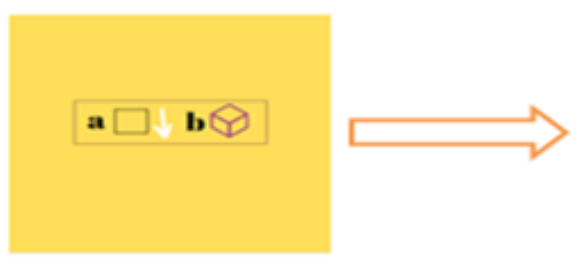

\section{$?$}

Construct the algebraic expression for the given resf ebe and calculate its value for $a=3, b=1$ 


\section{Appendix B}

Progressive Scoring Scale

\begin{tabular}{|l|l|l|}
\hline Problem & & \\
\hline$A$ & & Understanding the Problem \\
\hline & 3 & Understanding the problem entirely \\
\hline & 2 & Understanding some points of the problem \\
\hline & 1 & Being not able to understand the problem \\
\hline & 0 & Not showing any efforts to understand the problem \\
\hline & & Devising a Plan (Choosing a Strategy) \\
\hline & 3 & Choosing a strategy that can lead to an appropriate solution \\
\hline & 2 & Choosing only one part of strategy that can help solution \\
\hline & 1 & Choosing an inappropriate strategy \\
\hline$C$ & 0 & Not choosing any strategies \\
\hline & & Carrying Out the Plan \\
\hline & 3 & Finding suitable and correct solution \\
\hline & 2 & Finding a solution which is partly correct \\
\hline & 1 & Finding a solution which is inappropriate and incorrect \\
\hline$D$ & 0 & Not being able to find any solutions \\
\hline & & Looking Back \\
\hline & 3 & Solving the problem and newly created problem based on it \\
\hline & 2 & Verifying the results reasonably \\
\hline & 1 & Verifying the results partially \\
\hline$E$ & 0 & Not knowing how to verify the results \\
\hline & & Suggesting a Problem \\
\hline & 3 & The problem created is reasonable and solvable \\
\hline & 2 & A new problem has been created by changing values of the problem \\
\hline & 1 & The problem created is unreasonable and unsolvable \\
\hline & 0 & The same or new problem has not been suggested \\
\hline
\end{tabular}

\section{Appendix C}

The Guideline Prepared for Answering Performance Tasks

Performance tasks prepared to determine PSoSL were answered according to the instructions below.

a. Express the problem in your own words.

b. What is given in this problem? What is asked?

c. Explain how you are going to solve this problem.

d. Solve this problem.

e. Check the result you have found. Is it correct? If not, what mistakes have you made? Explain your answer.

f. Write a similar problem and solve it

\section{Copyrights}

Copyright for this article is retained by the author(s), with first publication rights granted to the journal.

This is an open-access article distributed under the terms and conditions of the Creative Commons Attribution license (http://creativecommons.org/licenses/by/4.0/). 